J. Clin. Chem. Clin. Biochem.

Vol. 17, 1979, pp. 235-239

\title{
A Rapid Enzymatic Assay for Methotrexate in Serum
}

\author{
By J. P. Persijn
}

From the Department of Clinical Chemistry (head Dr. J. P. Persijn), Division of Oncology, Antoni van Leeuwenhoek Hospital, Amsterdam, The Netherlands.

(Received June 19/November 2, 1978)

Summary: A kinetic enzymological assay for methotrexate in serum is described; the results are available after 1.5 hours. The lower limit of sensivity is $50 \mathrm{nmol} / 1$; the day-to-day variation coefficients compare favourably with other procedures (about $7 \%$ in the $200-600 \mathrm{nmol} / 1$ range). The method uses purified dihydrofolic acid reductase from bovine liver. The problem of its instability in the assay is circumvented by several measures, e.g. the use of a reaction rate analyser.

\section{Schnelle enzymatische Bestimmung von Methotrexat im Serum}

Zusammenfassung: Es wird eine kinetische Bestimmung von Methotrexat im Serum beschrieben, deren Ergebnisse in 1,5 Stunden erzielt werden können. Bei dem Verfahren wurde das Hilfenzym Dihydrofolatreduktase benutzt, das in der Gebrauchskonzentration einigermaßen instabil ist. Dieser Nachteil, wie auch die Instabilität anderer benötigter Reagenzien wurden durch verschiedene Maßnamen, z.B. durch die Anwendung eines automatischen Analysengerätes, beseitigt. Die Empfindlichkeitsgrenze beträgt $50 \mathrm{nmol} / 1$, der Variationskoeffizient im klinisch signifikanten Bereich von $200-600 \mathrm{nmol} / 1$ ist ungefähr $7 \%$.

\section{Introduction}

Methotrexate, an inhibitor of dihydrofolate reductase (EC 1.5.1.3), plays an important role in the treatment of several neoplastic diseases (1). In recent years large doses of methotrexate have been increasingly used. A serious problem is its toxicity, which can lead to life-threatening situations. The toxic effect of methotrexate is related to the rate of its disappearance in blood. The serum levels at about 48 hours and 72 hours after the start of administration of methotrexate are especially critical for the prediction of toxicity, and for the design of appropriate measures against it. Rapid quantitation of serum methotrexate, i.e. within a few hours of taking a blood sample is therefore necessary during therapy.

Competitive protein binding methods.(2-4) use short incubation periods (in the order of minutes) but involve laborious subsequent manipulations. Radioimmunological methods require long incubation periods $(6-36$ hours) $(5-8)$, and the results are therefore generally not available the same day.

The competitive protein binding and radioimmunological methods measure over a narrow range, in the order of a few tenths and a few hundred nmol/1, respectively. The methotrexate concentrations, however, may vary from zero to levels of a few $\mathrm{mmol} / \mathrm{l}$. It is therefore pure chance whether or not the chosen serum dilution for the first measurement is appropriate for the methotrexate concentration of the sample. Practice has shown that in some cases the measurements have to be repeated, not once but sometimes several times, to obtain measurable concentrations. This implies a clinically unacceptable long interval until the methotrexate concentration is known, if the above methods are used.

These disadvantages are less marked in enzyme inhibition assays (9-12), which yield results more quickly. The enzyme inhibition assay has been available for over ten years $(9-12)$, but descriptions are either not sufficiently detailed or do not fully take into account the various factors, e.g. instability of the reagents, period of validity of the calibration curve, effect of proteins, etc. We found that these factors have to be evaluated more fully before reproducible results can be obtained, and we adapted the enzymological method originally described by Bertino \& Fisher (12) to produce a reliable assay. In addition, the method presented here makes it possible to.assay various samples for methotrexate within 90 minutes, once the working solutions are ready for use, even if the above-mentioned repeated runs with different dilutions are required. 


\section{Materials and Methods}

Solutions and reagents

Phosphate buffer

Dissolve $6.5 \mathrm{~g} \mathrm{Na}_{2} \mathrm{HPO}_{4} \cdot 12 \mathrm{H}_{2} \mathrm{O}$ and $1.3 \mathrm{~g} \mathrm{NaH}_{2} \mathrm{PO}_{4} \cdot \mathrm{H}_{2} \mathrm{O}$ $(0.055 \mathrm{~mol} / \mathrm{l})$ in $500 \mathrm{ml}$ twice distilled water. Adjust $\mathrm{pH}$ to 6.50 .

\section{Dihydrofolic acid reductase}

Stock solution

Dihydrofolic acid reductase from bovine liver was purchased from Sigma Chemical Co., St. Louis, USA. It was obtained as a suspension of 1 or 5 Units in 0.230 or $0.150 \mathrm{ml}$ respectively of ammonium sulphate solution ( $3.6 \mathrm{~mol} / \mathrm{l})$. An aliquot of phosphate buffer is added to dihydrofolic acid reductase to prepare a solution of $2000 \mathrm{U} / 1$. This is stable for 2 weeks at $4^{\circ} \mathrm{C}$

Working reagent

The stock solution is diluted twenty times with cold $\left(4^{\circ} \mathrm{C}\right)$ phosphate buffer. The working reagent is unstable and should be used immediately after its preparation.

\section{Dihydrofolic acid solution}

Dihydrofolic acid was purchased from Sigma Chemical Co., St. Louis, USA, in sealed ampoules. Dihydrofolic acid (18 $\mathrm{mg})$ and $\mathrm{N}$-acetyl cysteine $(90 \mathrm{mg}$ ) are suspended in $30 \mathrm{ml}$ cold $\left(4^{\circ} \mathrm{C}\right) \mathrm{HCl}(0.005 \mathrm{~mol} / \mathrm{l})$. A fine suspension is obtained with the aid of a glass rod. While stirring, the suspension is transferred in $2.5 \mathrm{ml}$ aliquots to glass tubes. Stored, capped and frozen, this reagent is stable for two months.

The working reagent is prepared by thawing one aliquot, adding an equal volume of cold glycerol, and mixing.

\section{Methotrexate standard solution $(600 \mathrm{nmol} / \mathrm{l})$}

Methotrexate was produced by Lederle and designated as $94 \%$ pure. An aliquot $(4.0 \mathrm{mg})$ of methotrexate is dissolved in about $20 \mathrm{ml}$ twice distilled water. A minimal quantity of $1 \mathrm{~mol} / \mathrm{l}$ $\mathrm{NaOH}$ is added to promote dissolution. The volume is made up to $50.0 \mathrm{ml}$. The solution is diluted ten times with physiological saline to obtain $0.0176 \mathrm{mmol} / \mathrm{l}$. One $\mathrm{ml}$ of the latter preparation is thoroughly mixed with normal serum to give a final concentration of $600 \mathrm{nmol} / 1$. The standard in normal serum is stored in $1.1 \mathrm{ml}$ aliquots which are kept frozen at $-20^{\circ} \mathrm{C}$. Caution: Another commercial methotrexate batch was found to contain only $60 \%$ methotrexate "activity", resulting in a methotrexate concentration falsely increased by a factor of approx. 1.66 .

\section{NADPH solution $(0.002 \mathrm{~mol} / \mathrm{l})$}

This solution is prepared by dissolving an aliquot $(17 \mathrm{mg})$ of reduced nicotinamide-adenine dinucleotide phosphate (NADPH)tetrasodium salt (Boehringer Mannheim, enzymatic analysis $69 \%$, Grade II) in $10 \mathrm{ml} \mathrm{NaHCO}_{3}$ solution $(0.01 \mathrm{~mol} / \mathrm{l})$. This preparation is kept at room temperature and the unused portion is discarded at the end of the day.

\section{Incubation buffer}

The incubation buffer is prepared by mixing eight volumes of $\mathrm{H}_{2} \mathrm{O}$, one volume of $\mathrm{KCl}$ solution $(1.5 \mathrm{~mol} / \mathrm{l})$ and one volume of sodium citrate solution $(1.0 \mathrm{~mol} / \mathrm{l})$ and then adding $300 \mathrm{mg} \mathrm{N}$ acetyl cysteine $(18.4 \mathrm{mmol} / \mathrm{l})$ per $100 \mathrm{ml}$ of the above mixture. The $\mathrm{pH}$ should be carefully adjusted to 5.9 . The incubation buffer can be kept 3 weeks at $4^{\circ} \mathrm{C}$.

\section{NADPH buffer mixture}

NADPH solution $(0.1 \mathrm{ml})$ is added to $7.0 \mathrm{ml}$ incubation buffer. It should be prepared fresh before use.

Instrumentation

Settings of $L K B$ reaction rate analyser

Filter: 343 , reaction course: decrease, back off (A)O, range: $0-0.2$, measuring time 1.0 minute, chart speed $60 \mathrm{~mm} / \mathrm{min}$ temperature $30^{\circ} \mathrm{C}$.
Tab. 1. Method ology of the procedure for methotrexate

\begin{tabular}{|c|c|c|c|}
\hline & Control $^{1}$ ) & Standards & Samples ${ }^{3}$ ) \\
\hline $\begin{array}{l}\text { Incubation } \\
\text { buffer } \\
\text { NADPH buffer } \\
\text { mixture }\end{array}$ & $\begin{array}{l}1.0 \mathrm{ml} \\
10 \mu 1\end{array}$ & $\begin{array}{l}1.0 \mathrm{ml} \\
10 \mu \mathrm{l}\end{array}$ & $\begin{array}{l}1.0 \mathrm{ml} \\
10 \mu \mathrm{l}\end{array}$ \\
\hline Normal serum & $40 \mu \mathrm{l}$ & \multicolumn{2}{|c|}{$\begin{array}{c}0 \mu \mathrm{l} \text { or } 10 \mu \mathrm{l} \text { or } \\
20 \mu \mathrm{l} \text { or } 30 \mu \mathrm{l}\end{array}$} \\
\hline $\begin{array}{l}\text { Methotrexate } \\
\left.\text { standard in }{ }^{2}\right) \\
\text { serum }(600 \\
\text { nmol/1) }\end{array}$ & - & $\begin{array}{l}40 \mu l \text { or } 30 \mu l \\
20 \mu l \text { or } 10 \mu l\end{array}$ & or - \\
\hline Serum & - & - & $40 \mu l$ \\
\hline $\begin{array}{l}\text { Dihydrofolate } \\
\text { reductase } \\
\text { working reagent }\end{array}$ & $100 \mu 1$ & $100 \mu l$ & $100 \mu 1$ \\
\hline $\begin{array}{l}\text { Dihydrofolic } \\
\text { acid working } \\
\text { reagent }\end{array}$ & $\begin{array}{l}150 \mu l \\
\operatorname{mix}\end{array}$ & $\begin{array}{l}150 \mu 1 \\
\operatorname{mix}\end{array}$ & $\begin{array}{l}150 \mu \mathrm{l} \\
\operatorname{mix}\end{array}$ \\
\hline NADPH solutior & $\left.n^{4}\right) 100 \mu l$ & $100 \mu 1$ & $100 \mu 1$ \\
\hline
\end{tabular}

1) Activity at zero-concentration of methotrexate

${ }^{2}$ ) Total volume of normal serum and standard in normal serum is $40 \mu \mathrm{l}$.

3) Cerebrospinal fluid (CSF) can be measured by following the procedure for control, with the exception that $10 \mu \mathrm{l}$ CSF is added after addition of the NADPH buffer mixture. Then, normal serum etc. is added. To the standards, $10 \mu \mathrm{l}$ water is added to keep total volumes identical. After reading the standard curve results are multiplied by 4.0 .

$\left.{ }^{4}\right)$ Starting reagent.

\section{Assay procedure}

The methodology is described in table 1 . Immediately after adding the reagents the cuvettes should be placed in the racks and measurement should be started. The measurement is done with repeating units of two racks. We advise the following order: first rack: cuvettes containing "activity at zero concentration" of methotrexate, and standards $600,450,300$ and 150 (nmol/1), sample 1-5 (including control). Second rack: cuvettes with the duplicates of the cuvettes in the first. The third and the fourth racks should again contain standards and samples $6-10$ in the sequence as described for the first and second racks. Serum samples containing methotrexate in concentrations exeeding $600 \mathrm{nmol} / 1$ are diluted with the same normal serum as that used for the construction of the standard curve. If after completion of measurements some samples are to be assayed again (e.g. in diluted form), the whole procedure (standards, etc.) is repeated and freshly prepared dihydrofolic acid reductase working reagent should be used. Figure 1 shows a typical standard curve.

\section{Results and Discission}

Storage of dihydrofolic acid in hydrochloric acid, in the presence of a thiol to minimize air oxidation, is based on work published by Futterman (13) and has also been described by Falk et al. (10).

Using the solution of NADPH with bicarbonate, reproducible results were obtained with either fresh NADPH solutions or those prepared 6 hours before. It should be noted that, at the final NADPH concentration, about $70 \%$ of the optimal dihydrofolic acid reductase activity is obtained. Increasing the NADPH concentration did not seem attractive since dihydrofolic acid itself contributes 


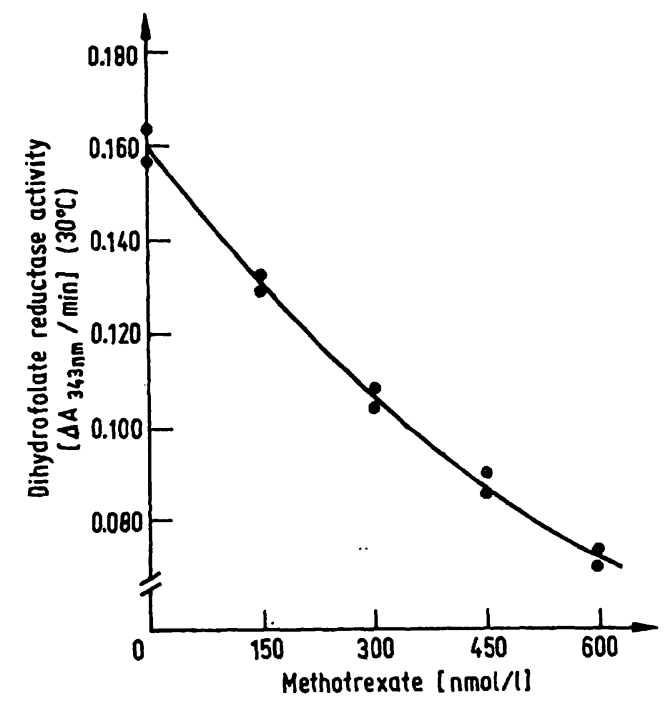

Fig. 1. The decrease of absorbance plotted against the methotrexate concentration. The standards were run in duplicate. The lowest concentration which could be measured was $50 \mathrm{nmol} / 1$.

considerably to the overall absorbance (13). We checked the occurrence of side reactions which could interfere with the assay. For this purpose we measured methotrexate in various sera with an increased serum 5 '-nucleotidase, which is an indication of liver disorders. The dihydrofolic acid was replaced by phosphate buffer containing ammonium sulphate in the same concentration as used in the dihydrofolic acid working solution. No change in absorbance could be registered. Identical observations were made when the enzyme working solution was replaced by buffer, the other reagents remaining unchanged.

Methotrexate is unstable in aqueous solution. After thawing of a frozen aqueous solution, persistent precipitates may form. For this reason a solution of methotrexate in normal serum was preferred as standard. Another reason for using methotrexate in normal serum as a standard is that, with an aqueous standard, higher activities have occasionally been measured in the absence than in the presence of serum. Surprisingly this effect was not always reproducible. It is our experience that, stored frozen, the standard in normal serum is stable for at least two months. During development of the method it was observed that the sequence of addition of reagents influences the slope and reproducibility of the standard curve. Preincubation with a very small quantity of NADPH, as recommended by Arons et al. (2), and the sequence of reagents as described in table 1, resulted in the steepest standard curve we could obtain. Unfortunately the reproducibility of the standard curve was less when the performance of the duplicates was delayed by placing the cuvettes of the duplicates in, say, the fifth rack. The reproducibility was even less when the recommended sequence of adding reagents was changed. Obviously some factor that we cannot explain shifts the standard curve in the course of time. This phenomenon may be illustrated by the following data.

Sera were measured together with controls during two weeks. For the control serum a pooled serum was prepared and aliquots were stored at $-20^{\circ} \mathrm{C}$. Two systems of performance were used. One involved the standards in duplicate only in the first rack and sera and control in the following racks. The other system involved the placement of sera and controls as described in Materials and Methods.

The former system gave for the control a mean value of $226 \mathrm{nmol} / 1$ with a standard deviation of $48 \mathrm{nmol} / 1$ $(\mathrm{n}=24)$; the latter system gave $220 \mathrm{nmol} / 1$ but with a standard deviation of $25 \mathrm{nmol}(\mathrm{n}=22)$. This discrepancy clearly illustrates that the procedure recommended should be followed.

Falk et al. (10) report that the standard curve is stable for 12 hours, but they use dihydrofolic acid reductase from a different source, i.e. an enzyme preparation from Lactobacillus casei which is not available to us. We assume that the interfering factor is related to the source of the enzyme preparation. If so, the method may be modified to a procedure using only one set of standards if other sources of enzyme preparations become available ${ }^{1}$ ).

An indication of the quality of the assay can be found in the results when two different dilutions of the sample are measured. Table 2 shows samples assayed either undiluted or in different dilutions (dilutions were performed with pipettes of the capilettor type Labora, Mannheim Germany). The data show that there is a direct relationship between methotrexate measured and dilution used, provided the methotrexate concentrations of the samples (diluted or undiluted) are not lower than about $100 \mathrm{nmol} / 1$ (see samples $2,6,7,16,18,19$ ). Thus samples with high methotrexate levels should not be so diluted for measurement as to reduce their methotrexate concentration below about $100 \mathrm{nmol} / \mathrm{l}$. Table 3 shows the interassay coefficients of variation for different ranges. They were calculated from duplicates of assays in routine samples performed during a period of two months. The table shows that the present method permits the assay of methotrexate with reasonable accuracy; an accuracy which exceeds that of radioimmunoassay procedures for comparable ranges (see l.c. (5)). The value of the decrease of absorbance per minute is changed by 0.05 as the concentration of methotrexate increases from zero to $300 \mathrm{nmol} / \mathrm{l}$. This compares favourably with the method of Falk et al. (10), who describes a $\Delta \mathrm{A}$ of approx. 0.015 under identical conditions of light path, temperature and concentration range of methotrexate.

1) After completion of the manuscript, a paper (R. J. Brooks, Clin. Chem. 24, 518 (1978)) came to our attention which describes the necessity of performing the assay on standards, controls and sera within 30 minutes when dihydrofolate reductase from bovine liver is used, while the standard curve is more stable when the enzyme from Lactobacillus casei is applied. 
Tab. 2. Results of measurement of methotrexate in all undiluted and diluted sera during an arbitrarily chosen period of 6 weeks.

Dilutions were done with normal serum. Except for samples 6, $9,17,19$ and 22 the samples had a methotrexate content exceeding $600 \mathrm{nmol} / \mathrm{l}$.

\begin{tabular}{|c|c|c|c|}
\hline Sample no. & $\begin{array}{l}\text { Dilution } \\
\text { factor }\end{array}$ & $\begin{array}{l}\text { Methotrexate } \\
\text { measured } \\
(\mathrm{nmol} / \mathrm{l})\end{array}$ & $\begin{array}{l}\text { Methotrexate } \\
\text { calculated } \\
(\mathrm{nmol} / \mathrm{l})\end{array}$ \\
\hline 1 & $\begin{array}{l}200 \\
400\end{array}$ & $\begin{array}{l}570 \\
290\end{array}$ & $\begin{array}{l}114,000 \\
116,000\end{array}$ \\
\hline 2 & $\begin{array}{r}4 \\
10 \\
20 \\
40\end{array}$ & $\begin{array}{r}350 \\
130 \\
65 \\
65\end{array}$ & $\begin{array}{l}1,400 \\
1,300 \\
1,300 \\
2,600\end{array}$ \\
\hline 3 & $\begin{array}{l}20 \\
50\end{array}$ & $\begin{array}{r}170 \\
75\end{array}$ & $\begin{array}{l}3,400 \\
3,750\end{array}$ \\
\hline 4 & $\begin{array}{l}200 \\
400\end{array}$ & $\begin{array}{l}310 \\
170\end{array}$ & $\begin{array}{l}62,000 \\
68,000\end{array}$ \\
\hline 5 & $\begin{array}{l}200 \\
400\end{array}$ & $\begin{array}{l}290 \\
135\end{array}$ & $\begin{array}{l}58,000 \\
54,000\end{array}$ \\
\hline 6 & $\begin{array}{r}1 \\
5 \\
10\end{array}$ & $\begin{array}{r}515 \\
95 \\
40\end{array}$ & $\begin{array}{l}515 \\
475 \\
400\end{array}$ \\
\hline 7 & $\begin{array}{r}3 \\
10\end{array}$ & $\begin{array}{r}245 \\
90\end{array}$ & $\begin{array}{l}735 \\
900\end{array}$ \\
\hline 8 & 3 & 225 & 665 \\
\hline 9 & 10 & 65 & 650 \\
\hline 9 & $\begin{array}{l}1 \\
2\end{array}$ & $\begin{array}{l}360 \\
180\end{array}$ & $\begin{array}{l}360 \\
360\end{array}$ \\
\hline 10 & 3 & 540 & 1,620 \\
\hline & 10 & 170 & 1,700 \\
\hline 11 & $\begin{array}{l}200 \\
300\end{array}$ & $\begin{array}{l}270 \\
215\end{array}$ & $\begin{array}{l}54,000 \\
64,000\end{array}$ \\
\hline 12 & $\begin{array}{l}2 \\
3\end{array}$ & $\begin{array}{l}335 \\
210\end{array}$ & $\begin{array}{l}670 \\
630\end{array}$ \\
\hline 13 & $\begin{array}{l}20 \\
40\end{array}$ & $\begin{array}{l}445 \\
215\end{array}$ & $\begin{array}{l}8,900 \\
8,600\end{array}$ \\
\hline 14 & $\begin{array}{l}500 \\
750\end{array}$ & $\begin{array}{l}440 \\
330\end{array}$ & $\begin{array}{l}220,000 \\
247,000\end{array}$ \\
\hline 15 & $\begin{array}{l}20 \\
40\end{array}$ & $\begin{array}{r}150 \\
90\end{array}$ & $\begin{array}{l}3,000 \\
3,600\end{array}$ \\
\hline 16 & $\begin{array}{r}500 \\
1000\end{array}$ & $\begin{array}{r}145 \\
50\end{array}$ & $\begin{array}{l}72,500 \\
50,000\end{array}$ \\
\hline 17 & $\begin{array}{l}1 \\
2\end{array}$ & $\begin{array}{l}430 \\
230\end{array}$ & $\begin{array}{l}430 \\
460\end{array}$ \\
\hline 18 & $\begin{array}{r}10 \\
50 \\
100\end{array}$ & $\begin{array}{r}545 \\
75 \\
0\end{array}$ & $\begin{array}{r}5,450 \\
3,750 \\
0\end{array}$ \\
\hline 19 & $\begin{array}{l}1 \\
2\end{array}$ & $\begin{array}{l}30 \\
20\end{array}$ & $\begin{array}{l}30 \\
40\end{array}$ \\
\hline 20 & $\begin{array}{r}8 \\
12\end{array}$ & $\begin{array}{l}230 \\
175\end{array}$ & $\begin{array}{l}1,840 \\
2,100\end{array}$ \\
\hline 21 & $\begin{array}{l}300 \\
500\end{array}$ & $\begin{array}{l}275 \\
175\end{array}$ & $\begin{array}{l}72,500 \\
87,500\end{array}$ \\
\hline 22 & $\begin{array}{l}1 \\
3\end{array}$ & $\begin{array}{l}480 \\
190\end{array}$ & $\begin{array}{l}480 \\
570\end{array}$ \\
\hline
\end{tabular}

Tab. 3. Coefficient of variation (C.V.) for different ranges of methotrexate concentration.

\begin{tabular}{cll}
\hline Range (nmol/l) & C.V. (\%) & Number of duplicates \\
\hline $0-100$ & 44.3 & 19 \\
$100-200$ & 24.0 & 51 \\
$200-300$ & 9.1 & 57 \\
$300-400$ & 6.6 & 26 \\
$400-500$ & 7.1 & 20 \\
$500-600$ & 5.1 & 15 \\
\hline
\end{tabular}

The instability of some working reagents makes it necessary to store them in a more stable stock form. Consequently some time-consuming manipulations are necessary at the start of the assay to prepare the final working reagent solutions. This limits the speed of the assay. On the other hand, application of the reaction rate analyser significantly reduces the total time required for the assay.

In addition, the rate analyser enables the technician to decide during the recording, whether the methotrexate concentration of the sample is suitable for the range of the standard curve. With the present method immediate repeat of the assay at alternative dilutions is possible until a measurable concentration of the diluted sample is obtained. Within two hours, the result can be reported to the clinician. If the laboratory is notified about 30 minutes in advance that a sample will be sent for methotrexate assay, the time required for the analysis, even if more samples are to be analysed at the same time, is only 90 minutes because some reagents can be prepared in the interval after notification. The need for methotrexate analysis, it should be added, is as a rule known much earlier than half an hour in advance.

This is of particular interest if adjustment of therapy is urgent. This advantage is not offered by any of the other methods such as microbiological (14), radioimmunological $(5-8)$ or direct ligand-binding assays (2-4). On the other hand, the radioimmunological and direct ligand-binding assays allow the measurement of very low concentrations of methotrexate (below $100 \mathrm{nmol} / \mathrm{l}$ ), but this is more of scientific than of clinical significance $(15,16)$.

Examples of disappearance of methotrexate from serum or cerebrospinal fluid as measured by the present method are given in figure 2. As can be expected

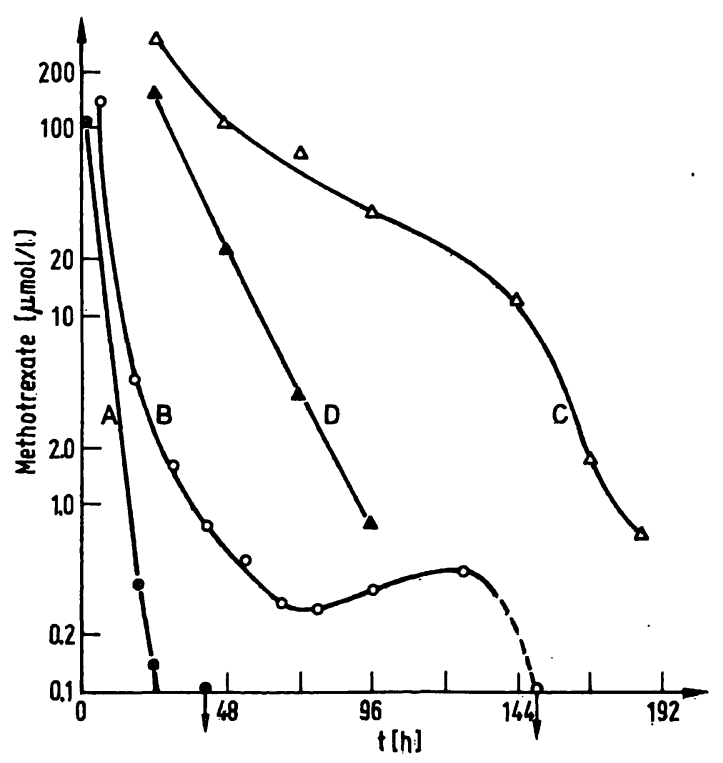

Fig. 2. Serum (circles) and cerebrospinal fluid (triangles) disappearance curves. Time zero marks the end of a six hour period of infusion (ciroles) or injection (triangles) in an Ommaya reservoir. Patient $A$ received $2 \mathrm{~g} / \mathrm{m}^{2}$. methotrexate, patient $B 6 \mathrm{~g} / \mathrm{m}^{2}$, patient $C 10 \mathrm{mg}$ and patient D $3 \mathbf{~ m g}$. 
from the disappearance rate in serum, no toxicity was observed in patient $\mathbf{A}$. This is in complete accordance with the data of Tattersall et al (15). In patient $B$ a slower disappearance was seen (serum value after 48 hours: $770 \mathrm{nmol} / 1$ ). After 72 hours there was a transient rise, as described by Wang et al (11). Severe myelosuppression followed as a toxic effect. Patient $\mathrm{C}$ suffering from breast cancer developed meningitis carcinomatosa. A delayed elimination of methotrexate from the cerebrospinal fluid was ascribed to disturbed cerebrospinal fluid circulation around the cerebral convexities resulting from carcinomatous adhesions. This was concluded from the observation that me thotrexate concentration in cerebrospinal fluid obtained by lumbar

\section{References}

1. Proceedings of the high-dose methotrexate therapy meeting, Cancer Chemotherapy Reports, Part 3 (Scientific editor: J.A.R. Mead), 6 (1975).

2. Arons, E., Rothenberg, S. P., da Costa, M., Fisher, C., \& Perwaiz Igbal, M. (1975), Cancer Research 35, 2033-2039.

3. Myers, C. E., Lippman, M. E., Eliot, H. M. \& Chabner, B. A. (1975), Proc. Nat. Acad. Sci. USA 72, 3683-3687.

4. Kamen, B. A., Takach, P. L., Vatev, R. \& Caston, J. D. (1976), Anal. Biochem. 70, 54-64.

5. Hendel, J., Sarek, L. J. \& Hvidberg, F. (1976), Clin. Chem. 22, 813-816.

6. Bohuon, C., Duprey, F.\& Boudene, C. (1974), Clin. Chim. Acta 57, 263-267.

7. Raso, V.\& Schreiber, R. (1975), Cancer Research 35, $1407-1410$

8. Paxtob, J. W. \& Rowell, F. J. (1977), Clin. Chim. Acta 80, 563-572. puncture was extremely low, while that in the ventricles was high.

In another similar case (patient D), with an apparently more normal cerebrospinal fluid circulation, the disappearance of methotrexate was much faster. More data obtained with the present method, involving a study of the disappearance rate of methotrexate after various routes of administration, will be given in another report.

\section{Acknowledgement}

The skilful assistance of Miss J. M. Dekker is gratefully acknowledged. I am indebted to Dr. H. M. Pinedo, University of Utrecht, for a gift of a batch of methotrexate.

9. Overdijk, B., van der Kroef, W. M. J., Visser, A. A. M. \& Hooghwinkel, G. J. M. (1975), Clin. Chim. Acta 59, 177 182.

10. Falk, L. C., Clark, D. R., Kalman, S. M. \& Long, F. (1976), Clin. Chem. 22, 785-788.

11. Wang, Y., Lantin, E. \& Sutow, W. (1976), Clin. Chem. 22, 1053-1056.

12. Bertino, J. R., Booth, B. A., Cashmore, A., Bieber, A. L. \& Sartorelli, A. C. (1963), Fed. Proc. 22, 183-189.

13. Futterman, S. (1957), J. Biol. Chem. 228, 1031-1038.

14. Chabner, B. A. \& Young, R. C. (1973), J. Clin. Invest 52, 1804-1810.

15. Tattersall, M. H. N., Parker, L. M., Pitman, S. W. \& Frei, E. (1975), Cancer Chemotherapy Reports Part 3, 6, 25-29.

16. Jaffe, N. \& Traggis, D. (1975), Cancer Chemotherapy Reports Part 3, 6, 31-36.

Dr. J. P. Persijn

Department of Clinical Chemistry Division of Oncology

Antoni van Leeuwenhoek Hospital Plesmanlaan 121

Amsterdam 
